\title{
エマルションに関する最近の進歩
}

\author{
阿 部 正 彦*,**
}

* 東京理科大学理工学部工業化学科 (干278 千葉県野田市山崎 2641)

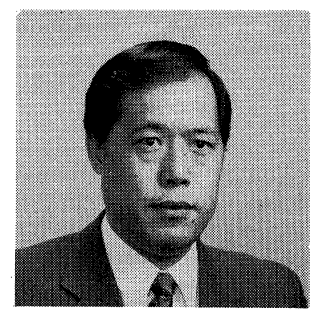

** 東京理科大学界面科学研究所 (T162 東京都新宿神楽坂 1-3)

\section{Recent Progress in Emulsion and Emulsion Technology}

\section{Masahiko $\mathrm{ABE}^{*, * *}$}

* Faculty of Science and Technology, Science University of Tokyo

(2641, Yamazaki, Noda-shi, Chiba-ken, 干278)

** Institute of Colloid and Interface Science, Science University of Tokyo (1-3, Kagurazaka, Shinjuku-ku, Tokyo, $\mp 162)$

Recent progress in emulsions and emulsion technology used in many fields is summarized. This paper deals mainly with definition, properties of microemulsion and macroemulsion, their applications in cosmetic, medical, and food fields, preparation of middle phase microemulsions, preparation and properties of multiple emulsions, zeta-potential of microemulsions, emulsionliquid membranes, and flotation separation of $\mathrm{O} / \mathrm{W}$ type microemulsion.

\section{1 はじめに}

エマルションは, 従来から, 食品, 化粧品, 医薬品, 潤滑剤, 塗料等の種々多岐にわたる製品や製造プロセ スに利用されており，最近ではまた，超微粒子の製 造 ${ }^{1)}{ }^{2)}$, 新規ポリマーの合成 ${ }^{3)}$, 有害有機物あるいは 重金属の回収 ${ }^{4)}$ や石油高次回収 ${ }^{5)}$ などの新規分野にも応 用されている。エマルションに関する最近の研究動向を 見てみると, 粒子径の大きいエマルションからサブミク ロン, ナノパーティクル, マイクロエマルション等のよ うな微細, 超微細粒子へ之移行し, また付加価值の向上 を目指した複合エマルション, ベシクル, リポソーム等 のコロイド次元分子集合体の調製及び物性に興味が持た れているようである。

本稿では, 紙面の制限もあるので, ごく最近に(ここ 2,3年間を主として) 発表されたマクロエマルションと マイクロエマルションに関する研究のいくつかを紹介す る。

\section{2 マイクロエマルションとマクロエマルション}

マイクロエマルションは, エマルションという言葉の イメージから，通常のエマルションと同一視されがちで あるが,これはまったく別のものである。1950 年ころ, Schulman $ら^{6) \sim 10)}$ は, イオン性界面活性剂/油/水の三 成分からなるエマルション溶液に中級アルコールを添加
することにより, 光学的に等方性であり, かつ, 透明な 流動性の良い液体が得られることを見いだした。これ を，エマルション滴が小さくなったものと解釈してマイ クロエマルションと命名した。1970 年代に入ると, エ ネルギー資源の確保が切望され, 石油の高次回収法 (Enhanced Oil Recovery, EOR) の一つであるマイセ ラーポリマー攻法（マイクロエマルションの利用）が非 常な関心を集めた。この研究に携わった研究者の多く は, 研究対象としていた系の組成が Schulman らのそ れとほとんど同じであったことから，マイクロエマル ションという表現を好んで用いたため，適切とは言えな いこの表現が定着したものと推察する。しかしその後, このマイクロエマルションは熱力学的に安定な可溶化系 であり，エマルションとは本質的に異なることが, 相

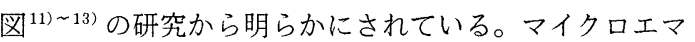
ルションは, 界面活性剤の存在により, 大量の水と油の それぞれを, あるいは両方を同時に溶解した均一系であ る。見方を変えると, 膨潤した大きなミセルが分散して いる系であり, 可溶化溶液亡本質的に同じである。参考 のために, エマルション (マクロ), マイクロエマル ション, 可溶化溶液, ミセル溶液の粒子径と光学的性質 をTable-1に示しておく。ただし，表中の粒子径だけ で判断してはいけないことは前述した通りである。

通常の可溶化条件下では, 油や水をそれほど多く溶解 することはできないが, 後述するような条件下では, 油 
Table-1 Relationship between particle sizes and optical properties of colloidal assemblies.

\begin{tabular}{|c|c|c|c|c|c|}
\hline & \multirow{2}{*}{$\begin{array}{c}\text { Particle size } \\
(\AA)\end{array}$} & \multirow{2}{*}{$\begin{array}{c}\text { External } \\
\text { appearance }\end{array}$} & \multicolumn{2}{|c|}{ Tyndall effect } & \multirow{2}{*}{$\begin{array}{c}\text { Thermodynamic } \\
\text { stability }\end{array}$} \\
\hline & & & Reflected light & Scattering light & \\
\hline \multirow[t]{2}{*}{ Emulsion } & $10,000 \sim 100,000$ & $\begin{array}{l}\text { Opaque like } \\
\text { milk }\end{array}$ & no & no & \multirow{2}{*}{ Unstable } \\
\hline & $1,000 \sim 10,000$ & Bluish white & Weak Blue & Weak Red & \\
\hline \multirow{2}{*}{ Microemulsion } & $500 \sim 1,000$ & $\begin{array}{c}\text { Translucency } \\
\text { (or Opalescency) }\end{array}$ & \multirow{2}{*}{ Blue } & \multirow{2}{*}{ Red } & \multirow{4}{*}{ Stable } \\
\hline & $200 \sim 500$ & \multirow{3}{*}{ Transparency } & & & \\
\hline Solubilized solution & $100 \sim 200$ & & no & no & \\
\hline Micellar solution & $50 \sim 150$ & & no & no & \\
\hline
\end{tabular}

と水を多量に，かつ同時に可溶化した無色透明 ${ }^{14)}{ }^{15)}$ あ るいは着色透明な溶液 ${ }^{16) ~ 20), ~}$ 半透明な溶液 ${ }^{21)}$. 22) も得 られる。また最近, 後述するように, 通常のマイクロエ マルションと全く同様な外観を呈する熱力学的に不安定 なマイクロエマルション（経時的に非常に安定な超微細 エマルション）の存在が報告されている ${ }^{23), 24)}$ 。

\section{3 化粧品分野}

HLB の調製や界面活性剂の選択を考慮せずに容易 に微細エマルションを調製できる方法として, 䉆谷 ら ${ }^{25) .26)}$ が開発した D 相 (界面活性剂相) 乳化法があ る。䇴谷ら ${ }^{27)}$ は最近, エーテル系非イオン界面活性剤/ ヘキサデカン/水/1,3ーブタジエン系の D 相乳化法によ る微細な $\mathrm{O} / \mathrm{W}$ 型エマルションの調製を検討し，等方性 の界面活性剂溶液 $\rightarrow$ 透明なゲル状 O/D エマルション $\rightarrow$ 微細な O/W 型エマルションの生成過程を相図を用いて 詳細に検討している。

乳化の過程やエマルション中に分子の高次構造体（液 晶）を形成させるとエマルションの生成・安定化に非常 に有利となり, 液晶相中に連続相としたい液相（油また は水）を多量に加えても液晶相が消失しない条件下で は, 三相エマルションを調製できるという報告 ${ }^{28)}$ があ る。鈴木ら ${ }^{29)}$ は, 低濃度から液晶を形成しやすいイオ ン性界面活性剂（リン酸デシルヘキシルアルギニン, $\left.\mathrm{R}_{6} \mathrm{R}_{10} \mathrm{MP}-\mathrm{Arg}\right)$ を用いて液晶乳化による三相エマル ションの調製法を検討している。Fig.ー1に，上記の界 面活性剤/油〔トリス (2-エチルヘキサノイル) グリセ リン〕/水/グリセリン系の液晶を利用した三相マイクロ エマルションの生成領域及び方法を示す。二相領域(II) において，いったん，O/LC (oil-in-liquid crystal) エマルションを生成させてから水を添加していくと液晶 が油滴の周りを取り囲んだ三相エマルション（微細な O/W 型エマルション）が生成するとしている。 また, 生成するエマルションの粒子径は, O/LCエマル

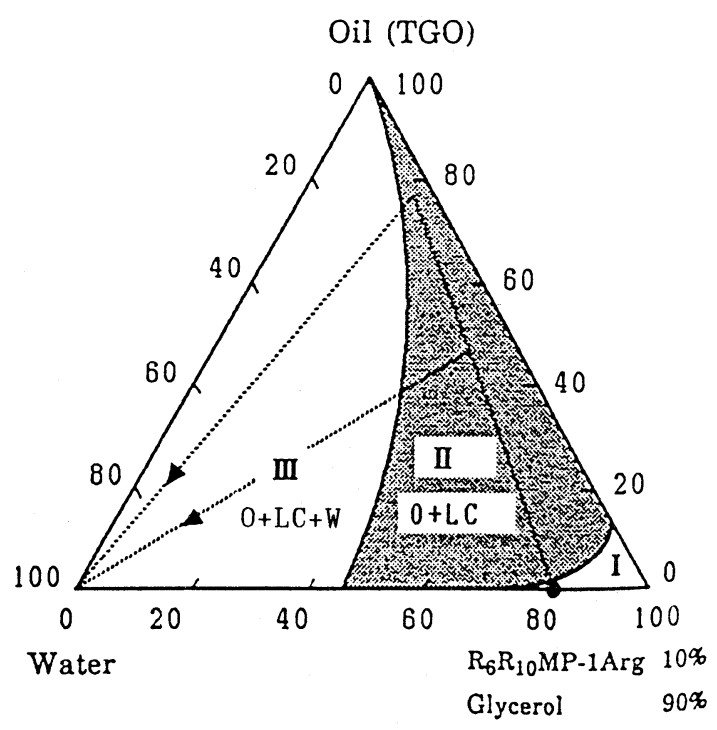

Fig. - 1 Changes in composition and state during the emulsion process (at $\left.25^{\circ} \mathrm{C}\right)^{29)}$.

ション生成時の機械的な力と, 油/界面活性剂比によっ て決定することができ, 半透明のサブミクロンエマル ションも調製できるとしている。

$\mathrm{HLB}$ 温度法の新しい展開が 2 つる。友政ら ${ }^{23) .24)}$ は, 非イオン界面活性剂/油/水系の温度を上昇させて可 溶化領域内で均一にした (O/W 型マイクロエマルション の生成) 後, 急冷させて超微細なエマルション（熱力学 的には不安定なマイクロエマルション）を調製する方法 を開発した。すなわち，完全に可溶化できる組成の範囲 内で調製し，また油と界面活性剂の量比を調節すると， 粒子径が制御された超微細なエマルションが得られる。 さらに，その安定性は，炭素鎖長の長い油や構造の大き い界面活性剤を用いると, 著しく向上するとしている。 また, Tamura ら ${ }^{30)}$ は, あらかじめ作成しておいたバ 
イコンティニュアス（ミドル相）マイクロエマルション を冷水中に添加することで超微細なエマルションを調製 する方法を開発した。

物理的手法を種々検討した研究がある。森田ら ${ }^{311}$ は, $\mathrm{O} / \mathrm{W}$ 型エマルションを調製するため乳化装置の性能試 験を行っており, 高圧ホモジナイザーを用いると, 乳化 剂の使用量の削減や乳化しにくい天然界面活性物質の乳 化も可能となり, 微細なエマルションが得られることを 報告している。今後, この装置を用いた効率良いW/O 型エマルションの調製が可能になれば，かなり普及する ものと思う。

その他, 國枝ら ${ }^{22)}$ によるガラスビーズを使った W/O 型ゲルエマルションの調製法がある。

\section{4 医薬品分野}

エマルションは, 栄養補給（静脈投与剂）に利用され たり, 最近では, 物理化学的に安定な $\mathrm{O} / \mathrm{W}$ 型エマル ションの油相に脂溶性薬物を溶解して薬効を期待する製 剂等として実用化されている。これは, ドラックキャリ ヤーエマルションあるいはリピッドマイクロスフェア

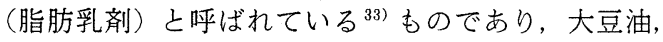
レシチン,グリセリンなどを含む $\mathrm{O} / \mathrm{W}$ 型エマルション である。この脂肪乳剂は, 生体に必須な電解質, アミノ 酸などを含む混合製剂が望まれることから, 石井ら ${ }^{34}$ は, このアミノ酸の等電点に着目して脂肪乳剤に与える 影響を検討しており, 脂肪乳剤とアミノ酸との混合製剤 の調製において，等電点を酸性側に持つ塩基性アミノ酸 を使用する必要があるとしている。また, 脂肪乳剂を静 脈内に投与する製剂として利用するためには油滴の平均

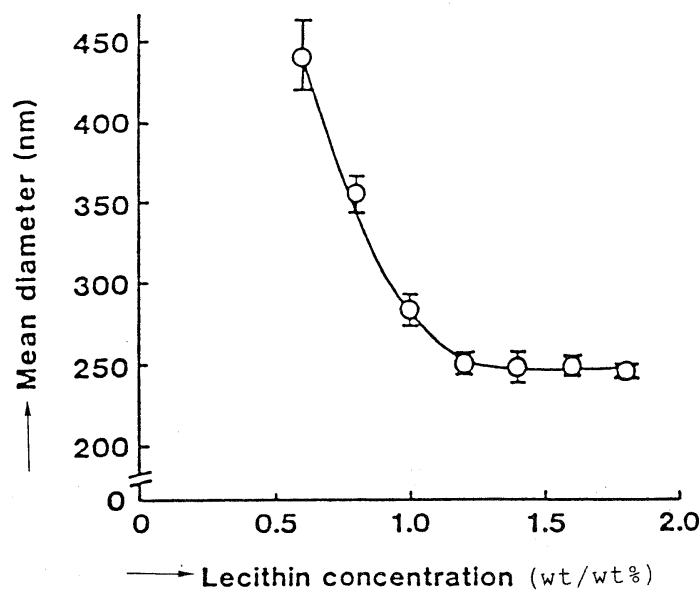

Fig.-2 Effect of egg lecithin concentration on the mean diameter of emulsion droplets in emulsion containing $10 \%(\mathrm{wt} / \mathrm{wt})$ soybean oil ${ }^{35)}$
粒径は $0.2 \sim 0.3 \mu \mathrm{m}$ 以下であることが必要であり, 乳 化剂としてレシチンを用いてエマルション(脂肪乳剤) を調製した場合， $1.2 \%$ 以上のレシチンを用いる之平均 粒子径は $250 \mathrm{~nm}$ 付近に保てると報告している ${ }^{35)}$ (Fig. -2)。彼ら ${ }^{36)}$ はまた, レシチンにより安定させたエマル ションを動物に投与し, 数種の動物の赤血球との相互作 用について検討している。溶血の程度は, 動物の赤血球 と, レシチンにより安定させたエマルションとの相互作 用に起因していることから, 薬剤のキャリヤーとしての エマルションの安全性の指標となりうるとしており, 数 種のエッグレシチン (EPC) を乳化剂として使用した場 合, 赤血球膜中の PC 含有量の増加並びに SM (Sphingomyelin) 含有量の減少に伴い, 溶血率は増加すると している。

Washington ${ }^{37)}$ は，コロイド系を用いた薬剤の投与 に関して実験的方法と数学的モデルを紹介しているの で，医薬品に興味を持たれる方は是非参考にされたい。

\section{5 食品分野}

エマルションは古くから食品分野へも応用されてお り，なかでも牛乳，バ夕ー，クリームなどの乳製品はそ の代表的なものである。乳製品への $\mathrm{W} / \mathrm{O} / \mathrm{W}$ 型複合工 マルションの応用に関しては, 総説 ${ }^{38)}$ があるので参考 にされたい。

乳製品等に使われる食品用エマルションは, タンパク 質を含んだものが多いが，タンパク質を用いたゲル状エ マルション粒子表面の微細構造についての研究が Jost ら ${ }^{39)} に よ り$ 報告されている。タンパク質やレシチンが 含まれた溶液に油相としてひまわり油を混合し，さらに 高圧ホモジナイザーをかけることにより，O/W 型エマ ルションを調製している (Fig.-3)。この $\mathrm{O} / \mathrm{W}$ 型エマ ルションに熱を加えた時のエマルション粒子表面の変化 をSEM（走査型電子顕微鏡）を用いて観察しており， 熱を加えて起こるゲル化により粒子は融合し，さらに分 散媒中に存在するタンパク質が粒子表面に吸着して広範 囲にわたり凝固するため, 初めは平面的であったエマル ション粒子表面の微細構造は “カリフラワー形” の特徵 的な構造となるとしている。また，高圧ホモジナイズ化 を繰り返すと，エマルション粒子表面に吸着するタンパ ク質が増加すること, あるいは, レシチン濃度が増加し たり， $\mathrm{O} / \mathrm{W}$ 型エマルション粒子径が隇少することによ り，加熱によるゲル化された粒子の強度は増加すること 等を述べている。このようなタンパク質やレシチンを用 いたゲル状 $\mathrm{O} / \mathrm{W}$ 型エマルションは，口当たりがよく， 滑らかであることから食品としての利用が期待されてい る。 


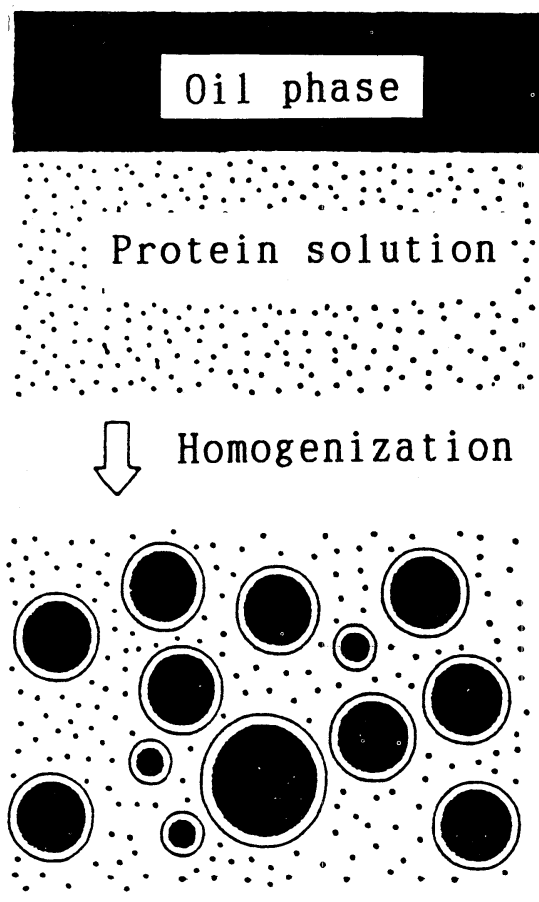

\section{\} Heat}

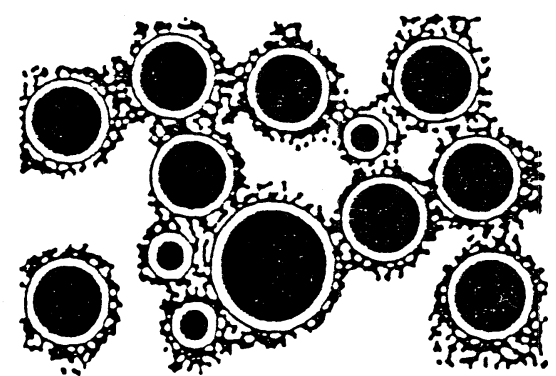

Fig.-3 Scheme illustrating steps in the formation of a lipid-rich gel based on a protein-

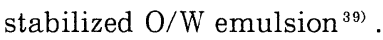

\section{6 ミドル相マイクロエマルションの調製}

國枝 ${ }^{40)}$ は, 塩水/イオン界面活性剂/コーサーファク タント/炭化水素系の場合, 圧力一定の下で 3 重臨界点 （水側, 油側の 2 つの臨界終点が一致した点において共 存する三相が同時に臨界溶解現象を起こす点）の自由度 は 1 であり，3 重臨界線が高温側に存在するため，その 温度以下では三相領域 (水相, マイクロエマルション 相, 油相）が出現すると説明している。

通常の場合, 適当な容器に, 界面活性剂/油/水系から なる溶液（コーサーファクタントや無機電解質を必要と する場合が多い）を密封し，充分に振とうかくはんして

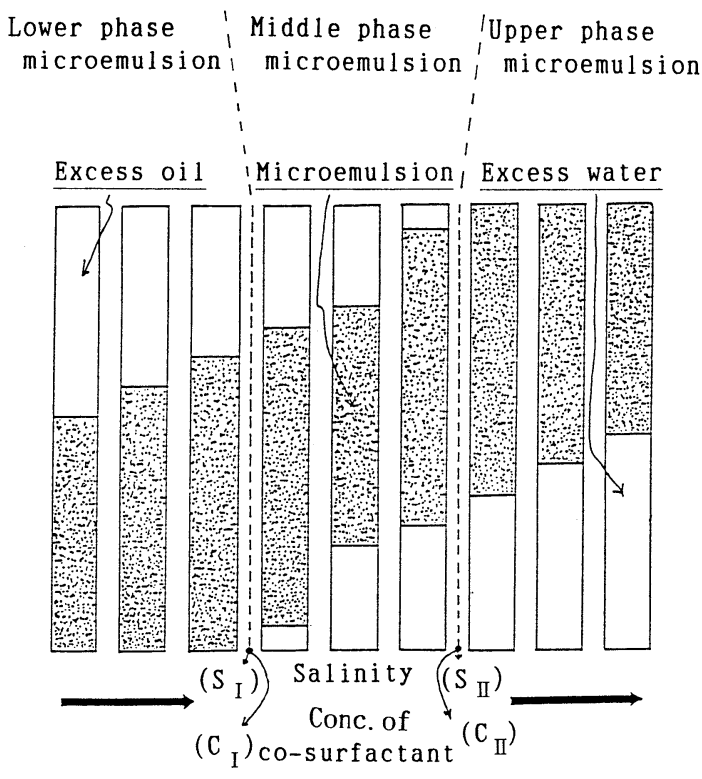

Fig.-4 Schematic presentation of the transition Lower $\rightarrow$ Middle $\rightarrow$ Upper of microemulsion phase in surfactant/oil/brine/alcohol systems by changing any of the variables.

から一定温度に保っておくと, 過剰相（水相や油相）を 伴ったマイクロエマルションが出現する。Fig. -4（エ チレンオキシド鎖等の親水基を含まないイオン界面活性 剤の場合）に示すように，塩水濃度を増加させると（右 方向), マイクロエマルション相は, 下相, 中間相, 上 相へと移行し, いわゆるウインザー型の相挙動 (Winsor I $\longleftrightarrow$ Winsor III $\longleftrightarrow$ Winsor II ） を示す（ただし，すべ ての界面活性剤が必ずしもウインザー型の相挙動を示す 訳ではない(11)）。三相領域を示す系では，油と水を同時 に可溶化しているマイクロエマルションが, 中間に存在 することからミドル相マイクロエマルション ${ }^{42)}$ ， ある いは界面活性剂が濃縮されていることから界面活性剂 相 ${ }^{43)}$ とも呼ばれる。このマイクロエマルションは, 界 面張力が極めて低い $\left(10^{-3} \mathrm{dyn} / \mathrm{cm}\right.$ 程度もしくはそれ以 下）之言われている。上記のウインザー型の相挙動は塩 水濃度以外の因子でも起こり, 例えば, アルコール $\left(\mathrm{C}_{4}, \mathrm{C}_{5}, \mathrm{C}_{6}\right)$ の濃度, 界面活性剂の濃度, 界面活性剂 の分子量, 油に対する塩水量を増加させたり, 温度や油 の炭化水素鎖長を減少させたりすると起こる。一般に,

イオン界面活性剂の場合は（耐硬水性をあげるためエチ レンオキシド鎖を導入したイオン界面活性剤も合成され ているので, 一概には言えないが）温度変化による転相 は起こりにくく, むしろアルコールや塩の濃度, 油と 水の比率により転相が起こる。非イオン界面活性剂の 場合, 温度の変化により $\mathrm{O} / \mathrm{W}$ 型と $\mathrm{W} / \mathrm{O}$ 型エマルショ 
Table-2 Effect of SCN and ACN on middle phase microemulsion formation in sodium alkyl sulfate/n-alkane/1hexanol/brine system at various temperature $\left(25 \sim 35^{\circ} \mathrm{C}\right)$

\begin{tabular}{c|c|c|c|c|c|c}
\hline ACN/SCN & 7 & 8 & 9 & 10 & 11 & 12 \\
\hline 8 & 0 & $\bigcirc$ & 0 & 0 & 0 & 0 \\
9 & 0 & 0 & 0 & $\bigcirc$ & 0 & 0 \\
10 & 0 & 0 & 0 & 0 & 0 & 0 \\
11 & 0 & 0 & 0 & 0 & 0 & 0 \\
12 & 0 & 0 & 0 & $\bigcirc$ & 0 & 0 \\
13 & 0 & 0 & 0 & $\bigcirc$ & 0 & 0 \\
14 & 0 & 0 & 0 & 0 & 0 & 0 \\
\hline
\end{tabular}

$\bigcirc$ : Formed, $\bigcirc$ : Unformed

ンの転相が起こる (Phase Inversion Temperature, $\left.\mathrm{PIT}^{44)}\right)$ 。

硫酸アルキル塩/コーサーファクタント $(1$ ーヘキサ ノール)/飽和炭化水素/塩 $(\mathrm{NaCl})$ 水系のミドル相マイ クロエマルション生成に及ぼす硫酸アルキル塩及びア ルカンの炭化水素鎖長の 影響を検討した例が, Table$2^{17)}$ 18) である(WOR $\left.=1,25 \sim 35^{\circ} \mathrm{C}\right) 。 \mathrm{ACN}$ 〔アルカン （油）の炭化水素鎖長] $-\mathrm{SCN}$ (界面活性剂の炭化水素鎖 長) $\leqq 3$ の場合のみ, ミドル相マイクロエマルションが 生成する。これらのミドル相マイクロエマルションの生 成屯, Winsor ${ }^{45)}$ の $\mathrm{R}$ 理論を発展させた Verzaro らの 式年）用いると理解しやすくなる。

最適塩濃度あるいは最適コーサーファクタント濃度に おいて極小值を示すミドル相マイクロエマルションの粒 子は, SCN 及び CCN（コーサーファクタントの炭化水 素鎖長）の增加に伴い膨潤するが, ACN 及び芳香族炭 化水素の置換基数の増加に伴い収縮する ${ }^{47)}$ 。また, こ の粒子径は, 温度の変化により膨潤と収縮を繰り返しな がら変化する ${ }^{14)}$ 。

ミドル相マイクロエマルションの生成には必ずしも コーサーファクタントの添加を必要としない ${ }^{16)}$ 場合が ある(Fig. -5)。Fig.-5 は，親水基の位置が異なるス ルホン酸型アニオン界面活性剤（炭化水素鎖長はすべて 18 である）を用いた場合のマイクロエマルション形成 に必要なコーサーファクタント ( $s$ ブチルアルコール) 量を表す。図から明らかなように，親水基の位置が 6 （すなわち他方は 12）や7（すなわち他方は 11）の場合 は，コーサーファクタントの添加を必要としない。コー サーファクタントは, 液晶を破壊するために添加し, 無 機電解質は界面活性剂のイオン解離の抑制のために添加 するが， ある意味では無機電解質もコーサーファクタン 卜と同じ効果を持つことになる。また，コーサーファク タントは必ずしもアルコールである必要はない47)。

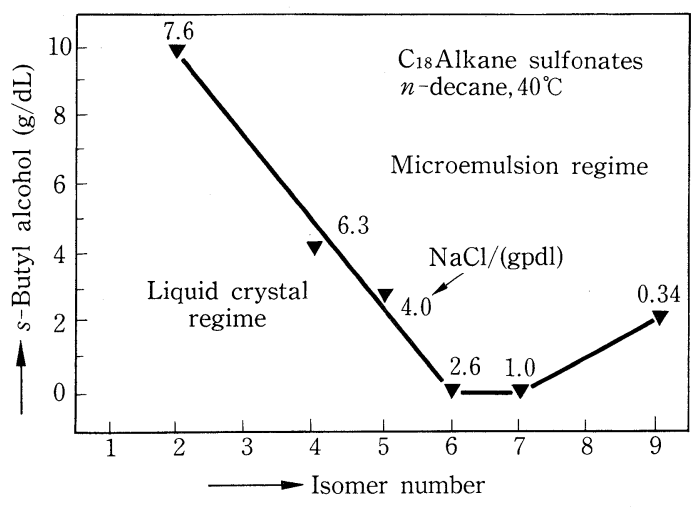

Fig.-5 Minimal cosolvent requirements for an isemeric series of alkane sulfonates.

前述した $\mathrm{R}$ 理論は，ミドル相マイクロエマルション 生成条件を定性的にしか解釈できないため, 定量的解釈 ができるようにする必要があり, 我々もミドル相マイク ロエマルション生成の熱力学的測定を行い, $R$ 理論の定 量化を試みている ${ }^{48)}$ 。國枝ら ${ }^{49) ~ 51) ~}$ は Griffin の HLB 值を用いて HLB 温度（ミドル相マイクロエマルション を生成する最適温度）を計算により求める方法を提唱し ておりており，これはかなり実用性に富んでいる。

ミドル相マイクロエマルションの構造に関しては, 種々の提案 ${ }^{52) ~ 54)}$ がなされているが，ミドル相マイクロ エマルションの生成はクリティカルに起こるのではなく ある領域で連続して起こり，その領域内では構造は一定 ではない場合 ${ }^{55)}$ や，カルボン酸型ア二オン界面活性剂 の場合のように生成したミドル相マイクロエマルション の重力場の位置によって異なっている場合 ${ }^{56)}$ や, 4 相領 域 ${ }^{57)}$ も現れることから, 過剩相の中間に生成するマイ クロエマルションの構造を画一化することは難しいもの と思わ机る。

\section{7 複合エマルション}

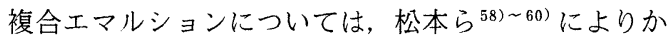

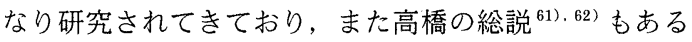
ので参考にして頂きたい。

松本ら ${ }^{60)}$ は, $0.5 \%$ のブドウ糖水溶液をマーカーとし て内水相に加え $\mathrm{W} / \mathrm{O} / \mathrm{W}$ 型エマルションを調製してか ら透析を行い，透析外液に含まれるブドウ糖量を Nelson-Somogyi 法により定量することによりその生成率 を求めている。さらに, 得られた生成率上親水性界面活 性剤に対するSpan 80 の重量比との関係を検討し, W/ $\mathrm{O} / \mathrm{W}$ 型エマルションの生成率に対する要因は, 試料の 調製に用いた親油性界面活性剤之親水性界面活性剂之の 比に関係するとしている。さらに，W/O/W 型エマル ションの内水相と外水相を等濃度のブドウ糖液で調製し 
た後純水で希釈すると, 油膜を介して内水相との間に濃 度勾配が生じるため, 外水相の水の一部が内水相に移動 して小胞体は膨潤するとしている。希釈後の時間に対す る小胞体の体積の増加との関係から, 希釈直後の内水相 への水の移動速度や内水相体積の増加速度を求めて油膜 の性質を検討している。この油膜面積の時間による変化 を測定することにより，W/O/W 型エマルションの安定 性や生成率を議論することが可能であるとしている等, この論文中では複合エマルションの調製, 挙動, 安定性 が総括されている。

\section{8 マイクロエマルションのゼータ電位}

$\mathrm{O} / \mathrm{W}$ 型マイクロエマルションのゼー夕電位及び粒子 径を測定した例が Fig.-6 ${ }^{64)}$ である。

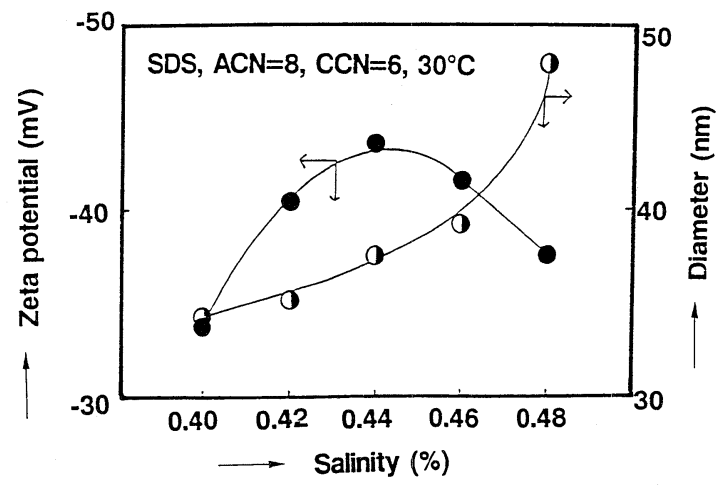

Fig.-6 Effect of salinity on zeta-potential and particle size of $\mathrm{O} / \mathrm{W}$ type microemulsion with sodium dodecyl sulfate at $30^{\circ} \mathrm{C}$.

塩濃度の增加に伴い粒子径は増加しているが, ゼー夕 電位は極大值を示す。そこで, 界面電気的考察を行った ところ, この極大值は電気二重層の変化によるものでは なく, マイクロエマルション表面の電荷密度の变化に依 存し, それは塩濃度の増加に伴う荷電分子（界面活性 剂）の吸着量の増加之表面積の增加の兼㸚合いによって 起こることが分かった。同系マイクロエマルション (コーサーファクタント変化系) のゼー夕電位もマイク ロエマルション表面の電荷密度に依存し, コーサーファ クタントの濃度の増加に伴いマイクロエマルション表面 から界面活性剂分子が脱着することが分かった ${ }^{64)}$ 。ま た, アミノ酸系両性界面活性剤マイクロエマルションの ゼー夕電位に及ぼす $\mathrm{pH}$ の影響を測定した ${ }^{65)}$ ところ， そのゼー夕電位は低 $\mathrm{pH}$ 領域において正の值を示した が, $\mathrm{pH}$ の増加に伴い減少し, 等電領域においても負の 值を示した。界面電気的考察を行うことにより，マイク ロエマルション表面に塩素イオンがナトリウムイオンよ りも優先的に結合していること，及びそれらのイオンの
STEP 1.Emulsion preparation

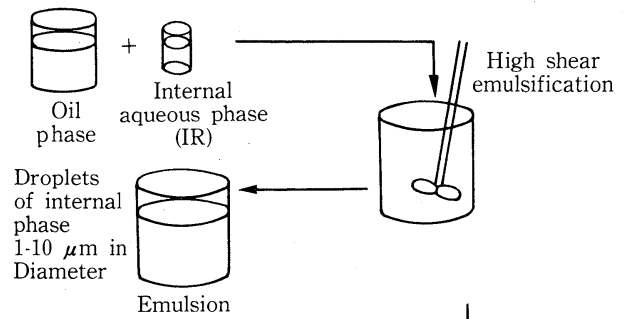

STEP 2.Extraction

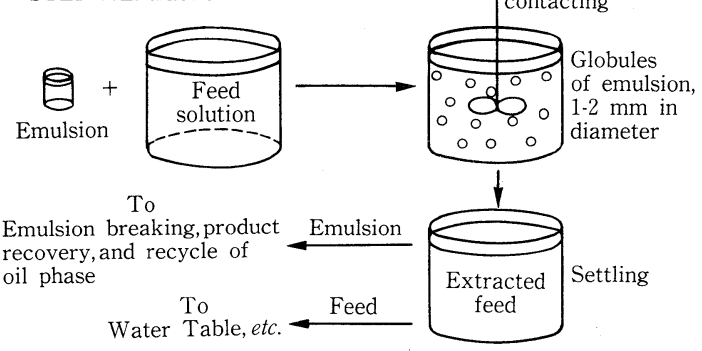

Fig. -7 Formation and use of liquid membranes ${ }^{66)}$. マイクロエマルションへの結合定数や界面活性剤の会合 数を求めることができた。

\section{9 エマルション液膜分離}

エマルションは, 分離法としても利用されており, 乳 化液膜分離法として知られている。乳化液膜法では, 界 面活性剤を含む油と内水相とを混合して $\mathrm{W} / \mathrm{O}$ 型エマル ションを作り，これを外水相中に分散させて $\mathrm{W} / \mathrm{O} / \mathrm{W}$ 型複合エマルションを調製する。その後, 外水相中の溶 質は, 油膜を通過して内水相中に濃縮されるため, この 内水相をセトラーを用いて分離することにより溶質を回 収することができる (Fig.-7) 66)。このような, 複合工 マルションを用いた乳化液膜法は，Li ら ${ }^{67)}$ により炭化 水素の分離が提案されて以来, 実用化のための様々な研 究が行わ机てきた。Li ら ${ }^{687.69)}$ は, フェノールの分離や 濃縮, 排水中の重金属の回収, 粗リン酸中のウランの回 収について検討しており, 溶媒抽出法よりもセトラー数 が少なくて済むことや, 溶剤の使用量が $1 / 18$ であるこ とから経済的に有利であることを示唆している。ここで 特筆すべきことは, W/O/W 型乳化液膜が Fürst ら ${ }^{70)}$ により廃液中の $\mathrm{Zn}$ の回収, 濃縮プラントとして実用化 段階に入ったことである。このような乳化液膜について の研究は, Li $ら^{66)}$ や, 寺本ら ${ }^{71)}$ 72) の優れた総説があ るので参考にして頂きたい。

\section{0 マイクロエマルションの破壊}

界面活性剤の回収及び再利用はコストの面からも重要 であり, マイクロエマルションそのものの破壊・分離が 不可欠之なる。マクロなエマルションの破壊について 


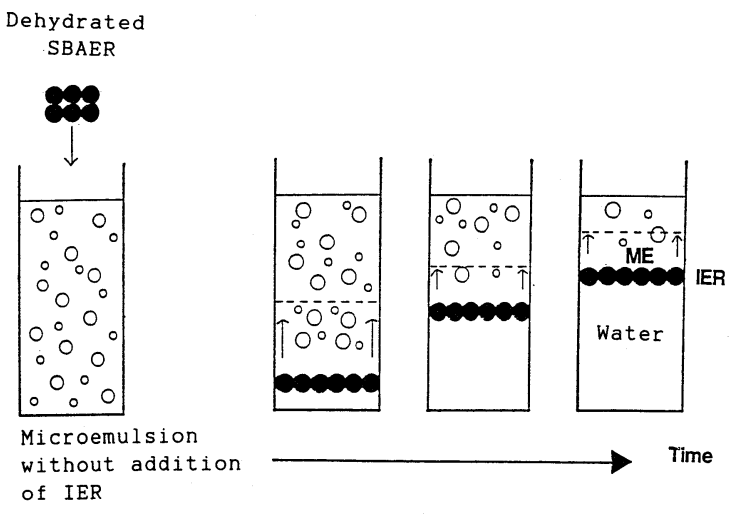

Fig.-8 Schematic model of spontaneous microemulsion-breaking.

は, オイルセパレーターによる浮上分離, 遠心分離, 電 気泳動及び電気浸透による分離, 乳化破壊剤添加による 分離がある ${ }^{73) ~ 75)}$ が, 静置安定性に優れたマイクロエマ ルションに適用した例はほとんどない。

アニオン界面活性剤マイクロエマルションの固体粒子 による自然破壊を試みてみた ${ }^{76), 77)}$ 。細孔容積, 粒子 径, 官能基, 表面状態の異なる高分子粒子を用いて検討 したところ，“脱水処理した”ア二オン交換樹脂（トリ メチルアミン基を持つ樹脂, Fig.-8 中の（○印）を下 相 $(\mathrm{O} / \mathrm{W}$ 型) マイクロエマルション相と静かに接触す ると，外的力を加えることなしに多量の水相がマイク ロエマルション相から分離し，イオン交換樹脂はマイク ロエマルションと水相の界面に常に存在することがわ かった (Fig. -8)。言い換えると，そのイオン交換樹脂 は, マイクロエマルションの破壊とともに試験管の底部 から徐々に浮上した。さらに，このようなマイクロエマ ルションの破壊は, イオン交換樹脂の添加量の増加に伴 い著しく加速し，樹脂量を体積比で $1 / 10$ に増加した之 ころ非常に短い時間で完全に水と油に分離できることを 見いだした ${ }^{77)}$ 。この方法は，脂肪酸含有非イオン界面 活性剤マイクロエマルションにも有効である。

\section{1 おりに}

エマルションの安定性に関する研究だけでも，ここ 3 年間の間に数百件にのぼり，また調製及び物性に関して もかなりの研究が行われている。マイクロエマルショ ン, 特に高付加価值を有するミドル相マイクロエマル ションの調製及び応用に関しても数多くの研究がある。 本稿では, これらの研究のほんの一部についてであり, 満足いくものとなり得ないが，いささかなりとも読者の お役に立てれば幸いである。

なお，この紙面をお借りして貴重な試料を提供して下 さった石井文由博士（明薬大）並びに鷺谷広道博士
（ポーラ横浜研）に感謝の意を表したい。 [平成 3 年 (1991 年) 11 月 5 日受理]

\section{文献}

1) K. Kandori, K. Kon-no, A. Kitahara, J. Colloid Interface Sci., 115, 579 (1987)

2) P. M. Kayima, S. Qutubuddin, J. Materials Sci. Letters, 8, 171 (1989)

3) E. Haue, S. Qutubuddin, J. Polym. Sci., 26, 429 (1988)

4) J.F. Scamehorn, J.H. Harwell, Eds., "Surfactant-Based Separation Processes", Marcel Dekker, New York (1989)

5) D.O. Shah, R.S. Schechter, Eds., "Improved Oil Recovery by Surfactant and Polymer Flooding”, Academic Press Inc., New York (1977)

6) T.P. Hoar, J.H. Schulman, Nature, 152, 102 (1943)

7) J.H. Schulman, D.P. Riley, J. Colloid Sci., 3, 383 (1948)

8) J.H. Schulman, J.A. Friend, J. Colloid Sci., 4, 497 (1949)

9) J.H. Schulman, W. Stoeckenius, L.M. Prince, J. Phys. Chem., 63, 1677 (1959)

10) W. Stoeckenius, J. H. Schulman, L.M. Prince, Kolloid Z., 169, 170 (1960)

11) K. Shinoda, Ed., "Solvent Properties of Surfactant Solutions”, Marcel Dekker, New York, (1967), p. 4

12) P. Ekwall, L. Mandell, K. Fontell, J. Colloid Interface Sci., 33, 215 (1970)

13) K. Shinoda, H. Kunieda, J. Colloid Interface Sci., 42, 381 (1973)

14) M. Abe, H. Nishino, K. Ogino, Sekiyu Gakkaishi, 32, 151 (1989)

15）西野宏, 桑原章史, 阿部正彦, 荻野圭三, 石油学会 誌, 33, 234 (1990)

16) M. Abe, D. Schechter, R.S. Schechter, W.H. Wade, U. Weerasooriya, S. Yiv, J. Colloid Interface Sci., 114, 342 (1986)

17）阿部正彦, 仲前昌人, 荻野圭三, 石油学会誌，31，458 (1988)

18）仲前昌人，阿部正彦，荻野圭三，石油学会誌，31，466 (1988)

19) M. Nakamae, M. Abe, K. Ogino, J. Colloid Interface Sci., 135, 449 (1990)

20）阿部正彦, 山崎忠男, 多田光一, 荻野圭三, 材料技術, 8, 313 (1990)

21) M. Abe, R.S. Schechter, R.D. Selliah, B. Sheikh, W.H. Wade, J. Dispersion Sci. Tech., 8, 157 (1987)

22) M. Abe, M. Nakamae, K. Ogino, W.H. Wade, Chem. Lett., 1987, 1613

23）友政 哲, 河内みゆき, 中島英夫, 油化学, 37, 1012 (1988)

24) H. Nakajima, T. Tomomasa, J. SCCJ., 23, 288 (1988)

25）䉆谷広道，服部孝雄，鍋田一男，永井昌義，日化，1983， 
1399

26) H. Sagitani, Y. Hirai, K. Nabeta, Yukagaku, 35, 102 (1986)

27) H. Sagitani, J. Dispersion Sci. Tech., 9, 115 (1988)

28）鈴木敏幸, フレグランスジャーナル, 4, 49 (1989)

29) T. Suzuki, H. Takei, S. Yamazaki, J. Colloid Interface Sci., 129, 491 (1989)

30) T. Tamura, M. Fujitsu, M. Fukuda, 6 th International Conference on Surface and Colloid Sci., preprints, p. 351 (1988)

31）森田正道, 片田順規, 油化学, 40, 58 (1991)

32) H. Kunieda, N. Yano, C. Solans, Colloid Surfaces, 36, 313 (1989)

33）石井文由, 製剤と機械, 131, 8 (1989)

34) F. Ishii, A. Takamura, H. Ogata, J. Pharm. Pharmacol., 40, 89 (1988)

35) F. Ishii, I. Sasaki, H. Ogata, J. Pharm. Pharmacol., 42, 513 (1990)

36) F. Ishii, Y. Nagasaki, H. Ogata, J. Pharmaceutical Sci., 78, 303 (1989)

37) C. Washington, Int. J. Pharm., 58, 1 (1990)

38) 高橋康之, 油化学, 35, 880 (1986)

39) R. Jost, F. Dannenberg, J. Rosset, Food Microstructure, 8, 23 (1989)

40) 國枝博信, マイクロおよびマイクロエマルションの性 質之応用講演会要旨集, (1990) p. 1

41) S. Qutubuddin, C.A. Millar, T. Fort, Jr., J. Colloid Interface Sci., 101, 46 (1984)

42) A. Graciaa, Y. Barakat, R.S. Schechter, W.H. Wade, S. Yiv, J. Colloid Interface Sci., 89, 217 (1982)

43) K. Shinoda, H. Arai, J. Phys. Chem., 68, 3485 (1964)

44) K. Shinoda, H. Saito, J. Colloid Interface Sci., 26, 70 (1968)

45) P.A. Winsor, Chem. Rev., 68, 1 (1968)

46) F. Verzaro, M. Bourrel, C. Chambu, "Surfactants in Solution" K.L. Mittal, P. Bothorel, Eds., Vol. 6, Plenum Press. (1986) p. 1137

47）山崎忠男, 仲前昌人, 阿部正彦, 荻野圭三, 石油学会 誌, 33, 241 (1990)

48）阿部正彦, 山崎忠男, 荻野圭三, 第 43 回コロイドおよ び界面化学討論会, 高松 (1990) p. 142

49) H. Kunieda, K. Shinoda, J. Colloid Interface Sci., 107 (1985)

50) H. Kunieda, N. Ishikawa, J. Colloid Interface Sci., 107, 122 (1985)

51) H. Kunieda, K. Hanno, S. Yamaguchi, K. Shinoda, J. Colloid Interface Sci., 107, 122 (1985)
52) S.J. Chen, D.F. Evans, B.W. Ninham, D.J. Mitchell, F.D. Blum, S.J. Pickup, J. Phys. Chem., 90, 842 (1986)

53) Y. Talmon, S. Prager, J. Chem. Phys., 69, 2984 (1978)

54) U. Olsson, K. Shinoda, B. Lindman, J. Phys. Chem., 90, 4083 (1986)

55) K. Ogino, M. Nakamae, M. Abe, J. Phys. Chem., 93, 3704 (1989)

56) M.J. Kim, M. Abe, K. Ogino, T. Kondo, T., to be submitted

57) H. Kunieda, H. Asaoka, K. Shinoda, J. Phys. Chem., 92, 185 (1988)

58）松本幸雄, 油化学, 35, 667 (1986)

59) S. Matsumoto, H. Makino, A. Ueno, A., J. Jpn. Oil Chem. Soc., 36, 320 (1987)

60) S. Matsumoto, W.W. Kang, J. Dispersion Sci. Tech., 10, 455 (1989)

61) Y. Takahashi, Jpn. J. Dairy Food Sci., 38, 253 (1989)

62）高橋康之, 表面, 28, 480 (1990)

63）荻野圭三, 阿部正彦, 仲前昌人, 大島広行, 近藤 保, 第 28 回油化学討論会・油化学研究発表会講演要旨 集, (1988) p. 84

64）荻野圭三, 阿部正彦, 仲前昌人, 西野 宏, 大島広行, 近藤 保, 日化第 58 春季年会講演要旨集 I, (1989) p. 753

65) M. Abe, A. Kuwabara, K. Ogino, H. Ohshima, T. Kondo, M.J. Kim, to be submitted

66) N.N. Li, E.C. Hsu, Sep. Sci. Technol., 20, 115 (1985)

67) N.N. Li, US Pat., 3,410,794 (1968)

68) N.N. Li, R.P. Cahn, D. Naden, R.W.M. Lai, Hydrometallurgy, 9, 277 (1983)

69) H.C. Hayworth, W.S. Ho, W.A. Burns, Jr., N. N. Li, Sep. Sci. Technol., 18, 493 (1983)

70) W. Fürst, J. Draxlar, R. Marr, Proc. World Congr. III Chem. Eng., 3, 331 (1986)

71）寺本正明, 三宅義和, 松山秀人, 表面, 25, 715 (1987)

72) M. Teramoto, MEMBRANE, 13, 13 (1988)

73) W.V. Truter, "Wool Wax," Interscience, New York (1956)

74) H. Yukawa, S. Kanai, O. Shimoyama, T. Karino, Chemical Engineering, 35, 656 (1971)

75) N.D. Sylvester, J.J. Byeseda, B. Yadeta, Ind. Eng. Chem. Prod. Dev., 8, 59 (1979)

76) M. Abe, H. Ohki, K. Kuwabara, W. Agui, K. Ogino, J. Colloid Interface Sci., 135, 598 (1990)

77）阿部正彦, 大木 博, 桑原克之, 案居院渡, 荻野圭三, 材料技術, 9, 127 (1991) 